\title{
Urološke komplikacije nakon transplantacije bubrega - iskustvo Referentnog centra u Hrvatskoj
}

\section{Urological complications after kidney transplantation - experience from Referral Center in Croatia}

\author{
Dean Markić ${ }^{1,2^{*}}$, Romano Oguićc ${ }^{1,2}$, Stanislav Sotošek ${ }^{1}$, Kristian Krpina ${ }^{1}$, Antun Gršković ${ }^{1}$, \\ Dražen Rahelić ${ }^{1}$, Ahel Juraj ${ }^{1}$, Nino Rubinićc ${ }^{1}$, Mauro Materljan ${ }^{1}$, Marin Trošelj ${ }^{1}$, Ivan Vukelićc ${ }^{1}$, \\ Klara Smolić ${ }^{1}$, Ivan Marin Sušanj ${ }^{3}$, Ante Jakšić ${ }^{1}$, Ana Bošnjak ${ }^{2}$, Josip Španjol ${ }^{1,2}$
}

\begin{abstract}
Sažetak. Cilj: Prikazati učestalost uroloških komplikacija nakon transplantacije bubrega u našem transplantacijskom centru. Ispitanici i metode: Retrospektivnim istraživanjem bili su obuhvaćeni svi pacijenti u Kliničkom bolničkom centru Rijeka u kojih je između 30. siječnja 1971. godine i 31. prosinca 2018. godine učinjena transplantacija bubrega. Rezultati: U promatranom razdoblju u našem transplantacijskom centru učinjeno je 1160 transplantacija bubrega. Urološke komplikacije imala su ukupno 154 pacijenta (13,3\%). Najčešće komplikacije su bile stenoza uretera u 52 pacijenta $(4,5 \%)$, urinarna fistula u 50 pacijenata $(4,3 \%)$, retencija urina u 23 pacijenta $(1,9 \%)$ te urolitijaza u 8 pacijenata $(0,7 \%)$. U većine pacijenata je provedeno kirurško liječenje. U posljednje vrijeme značajno se povećalo rješavanje uroloških komplikacija korištenjem minimalno-invazivnih metoda. U dvoje pacijenata $(0,17 \%)$ je zbog uroloških komplikacija došlo do gubitka grafta, a u troje pacijenata $(0,25 \%)$ su one dovele do smrtnog ishoda. Zaključak: Urološke komplikacije u našoj transplantacijskoj populaciji nisu česte. U pacijenata u kojih je potrebno kirurško liječenje endourološke metode predstavljaju danas inicijalnu metodu liječenja.
\end{abstract}

Ključne riječi: endourologija; transplantacija bubrega; urološke komplikacije

Abstract. Aim: To evaluate the incidence of urological complications after kidney transplantation in our transplant center. Patients and Methods: We retrospectively analyzed all patients with kidney transplantation operated in University Hospital Rijeka from January $30^{\text {st }} 1971$ to December 31 $1^{\text {st }}$ 2018. Results: In the observed period 1160 kidney transplantations were performed in our transplant center. Urological complications were noticed in the 154 patients (13.3\%). The most frequent complications were ureteral stenosis in 52 patients $(4.5 \%)$, urinary fistula in 50 patients $(4.3 \%)$, urinary retention in 23 patients (1.9\%) and urolithiasis in the 8 patients $(0.7 \%)$. The majority of the patients underwent surgical treatment. Recently, minimally invasive surgery was the method of choice for treatment of urological complications. In two patients $(0,17 \%)$ urological complications caused graft loss and in the three patients $(0,25 \%)$ this complications lead to death. Conclusion: Urological complications are not frequent in our transplant population. In the group of patients that required surgical treatment endourology methods are currently the initial treatment modality.

Key words: endourology; kidney transplantation; urological complications
${ }^{1}$ Klinika za urologiju, Klinički bolnički centar Rijeka, Rijeka, Hrvatska

${ }^{2}$ Medicinski fakultet Sveučilišta u Rijeci, Rijeka, Hrvatska

${ }^{3}$ Opća bolnica Koprivnica, Koprivnica, Hrvatska 


\section{UVOD}

Transplantacija bubrega najučinkovitija je metoda u liječenju terminalnog stadija bubrežne insuficijencije. Ona značajno smanjuje smrtnost (više od $60 \%$ u usporedbi s dijalizom), udvostručuje očekivano preživljenje i značajno unapređuje kvalitetu života ${ }^{1}$. Također, radi se o metodi koja je, u odnosu na dijalitičko liječenje, financijski isplativa već nakon prve godine liječenja ${ }^{2}$.

Urološke komplikacije mogu dovesti do značajnog morbiditeta, gubitka presatka, a mogu, doduše rijetko, biti i smrtonosne. One se najčešće događaju na ureterovezikalnoj anastomozi. Ekstravezikalna ureteralna anastomoza po metodi Lich-Gregoir ima najmanji broj komplikacija te se preporučuje njezina primjena. Dodatnu zaštitu predstavlja profilaktičko postavljanje ureteralne endoproteze (JJ).

Mnogi čimbenici utječu na uspješnost liječenja ovom metodom. Unaprjeđenje kirurške tehnike (primjerice korištenje ekstravezikalne metode prilikom implantacije uretera), kao i moderni imunosupresivni protokoli (smanjenje doze kortikosteroida) značajno su smanjili broj kirurških odnosno uroloških komplikacija. Urološke komplikacije su, međutim, i dalje značajan problem jer one mogu biti povezane sa značajnim morbiditetom, oštećenjem funkcije grafta, a ponekad mogu dovesti do gubitka presatka i smrti pacijenata. Urološke komplikacije dijelimo na rane (događaju se prvih 90 dana po transplantaciji) i kasne (zbivaju se nakon više od 90 dana po transplantaciji).

Cilj ovog rada je prikazati učestalost uroloških komplikacija nakon transplantacije bubrega u našem transplantacijskom centru te analizirati njihovo liječenje i ishod.

\section{ISPITANICI I METODE}

Retrospektivno je analizirana medicinska dokumentacija pacijenata u kojih je od 30. siječnja 1971. godine do 31. prosinca 2018. godine u Kliničkom bolničkom centru Rijeka učinjena transplantacija bubrega. Radi se o pacijentima koji su operirani na nekadašnjoj Klinici za kirurgiju Bolni- ce „Zdravko Kučić" - Sušak, a potom na Odjelu za urologiju i naposljetku od 2005. godine na Klinici za urologiju Kliničkog bolničkog centra u Rijeci.

Prvih osam godina našeg transplantacijskog programa ureter transplantiranoga bubrega je anastomoziran na nativni ureter (ureteroureterostomija). Nakon što bi se učinila ureteroureterostomija učinjena je ureterostomija in situ ili se postavila nefrostomija. Nakon što bi se snimkom na nefrostomiju dokazala očuvanost ureteroureteralne anastomoze, nefrostomija bi se odstranila.

Zbog relativno čestog razvoja komplikacija na ureteroureteralnoj anastomozi nakon prvih 140 transplantacija počela se koristiti ureterocistoneostomija (UCNS) po metodi Lich-Gregoir. Ta ekstravezikalna tehnika implantacije uretera se od tada kontinuirano koristi uz minimalne tehničke modifikacije. Radi sprječavanja komplikacija kod svakog UCNS-a se postavljao stent od pijelona bubrežnog presatka duž uretera u mjehur i probijanjem prednje stijenke mjehura se provukao na kožu. Posljednjih desetak godina se intraoperativno postavlja JJ ureteralna endoproteza koja se cistoskopski vadi $2-6$ tjedana nakon operacije.

Do kraja 2018. godine smo u 5 pacijenata učinili ortotopnu transplantaciju bubrega. U njih 4 učinjena je anastomoza između pijelona grafta i pijelona(uretera) primatelja, a u jednog pacijenta s urinarnom derivacijom učinjena je anastomoza uretera grafta na pouch.

U 5 pacijenata transplantacija bubrega učinjena je korištenjem urinarne derivacije te je ureter spojen na konduit ili pouch. $U$ jednoga od tih pacijenata došlo je do tromboze renalne vene te je učinjena uspješna retransplantacija. U jednog pacijenta u dječjoj dobi učinjena je augmentacija mjehura s kolonom te mu je presađen majčin bubreg uz anastomozu uretera na augmentirani mjehur.

\section{Statistička analiza}

Statističku obradu podataka učinili smo standardnim metodama uporabom kompjutorskog programa Statistica 13.5.0.17 (TIBCO Software, Palo Alto, CA, USA). Podaci su prikazani apsolutnom i relativnom učestalošću (frekvencijom i postocima). Učestalost komplikacija smo uspoređivali uz pomoć hi-kvadrat testa uz statističku značajnost od $p<0,05$. 


\section{REZULTATI}

Od 30. siječnja 1971. godine do 31. prosinca 2018. godine u našem centru učinjeno je ukupno 1160 transplantacija bubrega. Od toga su 362 $(31,2 \%)$ bile učinjene od živog darivatelja, a 798 (68,8 \%) od kadaveričnog darivatelja.

U prvih 140 (12,1 \%) transplantacija ureter transplantiranog bubrega je anastomoziran na nativni ureter (ureteroureterostomija) (tablica 1 ). $U$ to vrijeme najčešće komplikacije su bile na ureteralnoj anastomozi i to razvoj fistule $(11,4 \%)$, stenoze $(3,6 \%)$ i urolitijaze (3,6\%). Većina komplikacija $(60,5 \%)$ liječeno je konzervativno. Kirurško liječenje se, ovisno o uzroku, sastojalo od ponovnog šivanja anastomoze, resekcije anastomoze odnosno ureterolitotomije. $\mathrm{U}$ dvoje pacijenata urološke komplikacije dovele su do gubitka presatka, a smrtnog ishoda od uroloških komplikacija u tom razdoblju nije bilo. Također su zabilježene i komplikacije u vezi $s$ drenažnom protezom urinarne anastomoze, a koje su u većine pacijenata liječene konzervativnim pristupom.

Zbog relativno visokoga postotka razvoja komplikacija na ureteroureteralnoj anastomozi, nakon osam godina počela se koristiti UCNS, a to je standardna metoda koju koristimo i danas. U tom drugom razdoblju učinilo smo ukupno 1020 transplantacija. U velike većine tih pacijenata (1010 pacijenata - $99 \%$ ) učinjen je UCNS, u 5 pacijena- ta je ureter anastomoziran na konduit ili pouch, $\mathrm{u}$ jednog na augmentirani mokraćni mjehur (ko(on), a u 4 pacijenta s ortotopnom transplantacijom učinjena je anastomoza između pijelona grafta i pijelona(uretera) primatelja (tablica 2). Ukupna pojavnost uroloških komplikacija bila je znatno manja nego u prvom razdoblju (tablica 3). Stenoza je bila najčešća komplikacija $(4,6 \%)$, a većina komplikacija $(81,9 \%$ ) liječena je kirurškim pristupom (slika $1-3$ ). Kirurško liječenje ovisilo je o tipu komplikacije, pa se tako, primjerice, kod stenoze i nekroze uretera najbolja pokazala terminolateralna anastomoza pijelona grafta i nativnoga uretera.

Nativni ipsilateralni ureter najčešće se koristio za zamjenu uretera presatka. Kada to nije bilo moguće ureter presatka zamijenjen je segmentom ileuma ( 3 pacijenta). $U$ četiri pacijenta učinjena je ureterocistoneostomija po Boariju, a kod jednog je učinjena transureteroureterostomija. $U$ dvoje pacijenata s ortotopnom transplantacijom bubrega učinili smo pijelopijeličnu anastomozu, ali je došlo do razvoja urinarne fistule na mjestu anastomoze, te je uspješno učinjena pijeloplastika (modifikacija Anderson-Hynesove operacije).

$\mathrm{U}$ pacijenta $\mathrm{s}$ augmentacijom mokraćnoga mjehura došlo je do razvoja kamenca u pijelonu, te mu je uspješno učinjena mini perkutana nefrolitotripsija (mini PCNL). Uzrok nastanka kamenca bila je stenoza anastomoze uretera i augmentiranog mjehura

Tablica 1. Urološke komplikacije u prvih 140 transplantacija bubrega u kojih je učinjena ureteroureterostomija

\begin{tabular}{|c|c|c|c|c|c|}
\hline \multirow{2}{*}{ Komplikacija } & \multirow{2}{*}{$\mathbf{N}(\%)$} & \multicolumn{4}{|c|}{ Liječenje } \\
\hline & & Konzervativno & Rezultat & Operacija & Rezultat \\
\hline Fistula ureteralne anastomoze & $16(11,4 \%)$ & 12 & 1 kasna stenoza & 4 & dobar \\
\hline Stenoza & $5(3,6 \%)$ & 1 & i dalje stenoza & 4 & $\begin{array}{c}1 \text { dobar } \\
3 \text { razvoj } \\
\text { renalne } \\
\text { insuficijencije }\end{array}$ \\
\hline Urolitijaza & $5(3,6 \%)$ & 1 & dobar & 4 & $\begin{array}{l}2 \text { dobar } \\
2 \text { recidiv }\end{array}$ \\
\hline Kalikokutana fistula & $1(0,7 \%)$ & / & / & 1 & nefrektomija \\
\hline Bilateralni epididimitis & $1(0,7 \%)$ & 1 strana & dobar & 1 strana & orhiektomija \\
\hline \multicolumn{6}{|c|}{ Komplikacije u vezi s drenažnom protezom urinarne anastomoze: } \\
\hline Urinarna fistula & $8(5,7 \%)$ & 6 & dobar & 2 & dobar \\
\hline Krvarenje & $6(4,3 \%)$ & 5 & dobar & 1 & dobar \\
\hline Opstrukcija uretera & $1(0,7 \%)$ & / & / & 1 & dobar \\
\hline Ukupno & $43(30,7 \%)$ & $26(60,5 \%)$ & & $17(39,5 \%)$ & \\
\hline
\end{tabular}


Tablica 2. Urološke komplikacije u preostalih 1020 transplantacija bubrega kod kojih je u velike većine pacijenata učinjena ureterocistoneostomija (UCNS)

\begin{tabular}{|c|c|c|c|c|c|}
\hline \multirow{3}{*}{ Komplikacija } & \multirow{3}{*}{$\mathbf{N}(\%)$} & \multicolumn{4}{|c|}{ Liječenje } \\
\hline & & \multicolumn{2}{|c|}{ Konzervativno } & \multicolumn{2}{|c|}{ Operacijsko } \\
\hline & & $\mathbf{N}$ & Rezultat & $\mathrm{N}$ i metoda & Rezultat \\
\hline Fistula ureteralne anastomoze & $\begin{array}{c}13 \\
(1,3 \%)\end{array}$ & 4 & $\begin{array}{l}3 \text { dobar } \\
1 \text { smrt } \\
\text { (sepsa) }\end{array}$ & $\begin{array}{l}1 \text { ureterostomija } \\
3 \text { šavi na UCNS } \\
1 \text { T-T ureteroureterostomija } \\
1 \text { Boari } \\
1 \text { JJ proteza } \\
2 \text { pijeloplastika }\end{array}$ & $\begin{array}{l}1 \text { smrt (embolija) } \\
3 \text { dobar } \\
1 \text { odgođeno cijeljenje } \\
1 \text { dobar } \\
1 \text { dobar } \\
2 \text { dobar }\end{array}$ \\
\hline Nekroza uretera & $\begin{array}{c}9 \\
(0,9 \%)\end{array}$ & / & / & $\begin{array}{l}1 \text { pijeloileocistoplastika } \\
1 \text { Boari } \\
3 \text { T-T pijeloureterostomija } \\
3 \text { T-L pijeloureterostomija } \\
1 \text { reUCNS }\end{array}$ & $\begin{array}{l}\text { Megaloop sy. } \\
\text { dobar } \\
2 \text { dobar } \\
1 \text { fistula (reop.) } \\
\text { dobar } \\
\text { dobar }\end{array}$ \\
\hline Stenoza & $\begin{array}{c}47 \\
(4,6 \%)\end{array}$ & 4 & $\begin{array}{l}4 \text { dobar } \\
\text { (postavljen } \\
\text { PNS koji je } \\
\text { kasnije } \\
\text { skinut) }\end{array}$ & $\begin{array}{l}1 \text { pijeloileocistoplastika } \\
2 \text { Boari } \\
1 \text { šavi na UCNS } \\
1 \text { korekcija UCNS } \\
3 \text { reUCNS } \\
8 \text { T-T uretero(pijelo)- } \\
\text { ureterostomija } \\
1 \text { transuretero- ureterostomija } \\
15 \text { T-L uretero(pijelo)- } \\
\text { ureterostomija } \\
1 \text { endourološka resekcija } \\
5 \text { retrogradna dilatacija } \\
5 \text { antegradna dilatacija }\end{array}$ & $\begin{array}{l}\text { dobar } \\
1 \text { (KRI) } \\
1 \text { dobar } \\
\text { dobar } \\
\text { dobar } \\
\text { dobar } \\
7 \text { dobar } \\
1 \text { odljevni kamenac } \\
\text { dobar } \\
\text { dobar } \\
\text { dobar } \\
2 \text { dobar } \\
3 \text { T-L uretero(pijelo)- } \\
\text { ureterostomija } \\
3 \text { dobar } \\
1 \text { pijeloileocistoplastika } \\
1 \text { pijeloureterostomija }\end{array}$ \\
\hline Urolitijaza & $\begin{array}{c}3 \\
(0,3 \%)\end{array}$ & / & / & $\begin{array}{l}1 \text { ureteroileocistoplastika } \\
1 \text { miniPCNL } \\
1 \text { endoskopska litotripsija }\end{array}$ & $\begin{array}{l}\text { smrt (zatajenje jetre) } \\
\text { dobar } \\
\text { dobar }\end{array}$ \\
\hline $\begin{array}{l}\text { Krvarenje iz ureterovezikalne } \\
\text { anastomoze }\end{array}$ & $\begin{array}{c}6 \\
(0,6 \%)\end{array}$ & 5 & dobar & 1 koagulacija & dobar \\
\hline Epididimitis & $\begin{array}{c}7 \\
(0,7 \%)\end{array}$ & 5 & dobar & 2 orhidektomija & dobar \\
\hline Retencija urina & $\begin{array}{c}23 \\
(2,3 \%)\end{array}$ & 1 & dobar & $\begin{array}{l}12 \text { TURP } \\
6 \text { discizija vrata mjehura } \\
4 \text { interna uretrotomija }\end{array}$ & $\begin{array}{l}\text { dobar } \\
5 \text { dobar } \\
1 \text { urinski kateter } \\
\text { dobar }\end{array}$ \\
\hline Lezija uretera & $\begin{array}{c}2 \\
(0,2 \%)\end{array}$ & / & / & $\begin{array}{l}1 \text { reUCNS } \\
1 \mathrm{JJ} \text { proteza }\end{array}$ & $\begin{array}{l}\text { dobar } \\
\text { smrt (pneumonija) }\end{array}$ \\
\hline Fistula mokraćnog mjehura & $\begin{array}{c}1 \\
(0,1 \%)\end{array}$ & 1 & dobar & / & / \\
\hline Ukupno & $\begin{array}{c}111 \\
(10,9 \%)\end{array}$ & 20 & & 91 & \\
\hline
\end{tabular}

T-T: terminoterminalno; T-L: terminolateralno; PCNL: perkutana nefrolitotripsija; TURP: transuretralna resekcija prostate; PNS: perkutana nefrostomija 
Tablica 3. Najčešće urološke komplikacije u 1160 transplantiranih pacijenata ovisno o vrsti učinjene ureteralne anastomoze u dva promatrana razdoblja

\begin{tabular}{|c|c|c|c|c|}
\hline \multirow{2}{*}{ Komplikacije } & \multirow{2}{*}{$\begin{array}{l}\text { Ukupno } \\
\text { (N-\%) }\end{array}$} & \multicolumn{2}{|c|}{ Razdoblje } & \multirow{2}{*}{$p$} \\
\hline & & I & II & \\
\hline Urinarna fistula & $50(4,3 \%)$ & $25(17,9 \%)$ & $25(2,5 \%)$ & $p<0,01$ \\
\hline Stenoza uretera & $52(4,5 \%)$ & $5(3,6 \%)$ & $47(4,6 \%)$ & $p>0,05$ \\
\hline Urolitijaza & $8(0,7 \%)$ & $5(3,6 \%)$ & $3(0,3 \%)$ & $p<0,01$ \\
\hline
\end{tabular}

Razdoblje I: prvih 140 transplantacija s ureteroureteralnom anastomozom, razdoblje II: sljedećih 1020 transplantacija s ureterocistoneostomijom
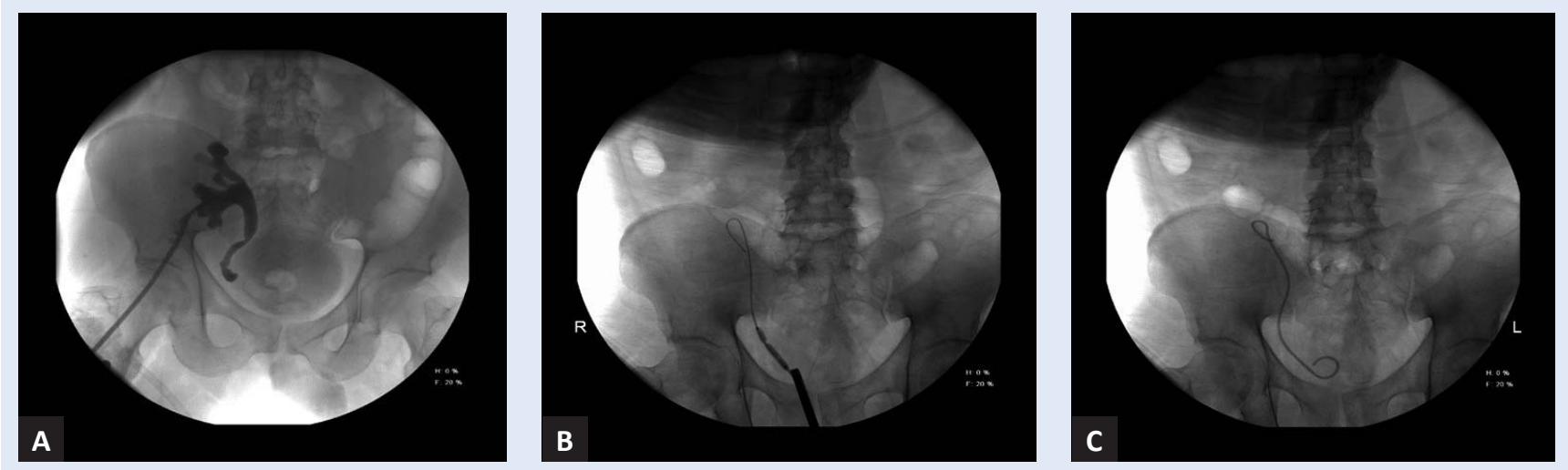

Slika 1. Retrogradna balonska dilatacija stenoze uretera transplantiranoga bubrega. Antegradnom snimkom dokazana je stenoza uretera $(A)$, potom je učinjena retrogradna balonska dilatacija stenoze uretera $(B)$ i postavljen JJ (C).

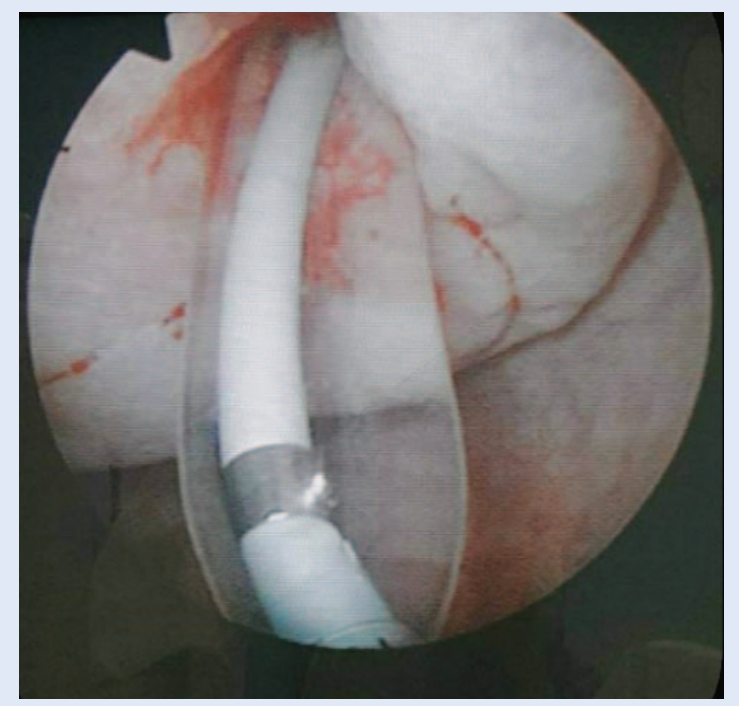

Slika 2. Endoskopski prikaz retrogradne balonske dilatacije stenoze terminalnog dijela uretera presatka

(kolon) te je istodobno učinjena i uspješna antegradna balonska dilatacija. U jednog pacijenta $\mathrm{s}$ urinarnom derivacijom (Mainz-pouch I) došlo je do nastanka kamenca u pouchu te je učinjena uspješna endoskopska litotripsija.

U 23 pacijenta imali smo prisutnu kompletnu ili značajnu inkompletnu retenciju urina s recidivira-

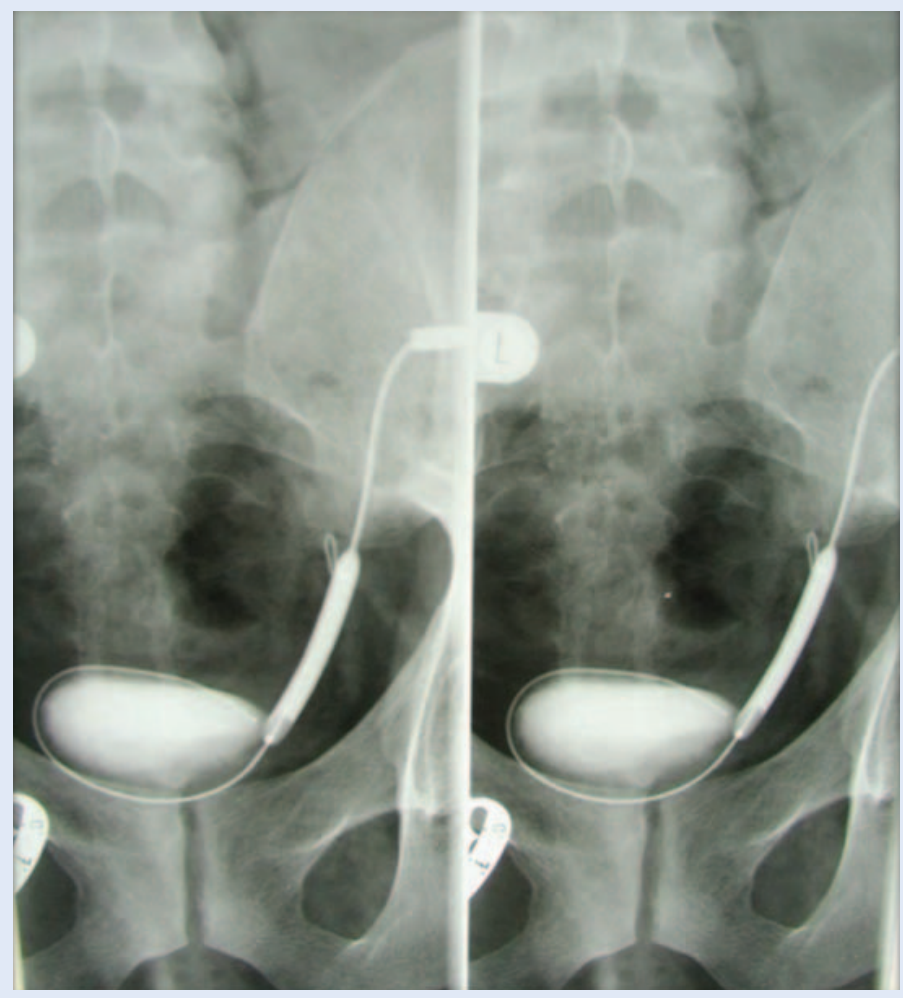

Slika 3. RTG prikaz antegradne dilatacije stenoze uretera presatka 
jućim urinarnim infekcijama. U jednog pacijenta ona je riješena primjenom alfa-blokatora i finasterida, a svi ostali pacijenti su operirani. Najčešći uzrok opstrukcije bila je benigna hiperplazija prostate, skleroza vrata mjehura i striktura uretre.

U drugom smo razdoblju imali 3 pacijenta (dva pacijenta s urinarnom fistulom i jedan s urolitijazom) u kojih je došlo do smrtnog ishoda.

Vrijedno je spomenuti da smo 2007. godine učinili i izvantjelesno mrvljenje kamenaca šoknim valovima (ESWL) u ureteru transplantiranoga bubrega. Radilo se o pacijentu u kojega je 1993. učinjena en-bloc transplantacija bubrega u drugoj državi. Četrnaest godina nakon transplantacije došlo je do razvoja opstruktivne uropatije te mu je pronađen kamenac u ureteru medijalnije položenog bubrega. Kamenac je uz pomoć ESWL-a uspješno dezintegriran te ga je pacijent izmokrio.

\section{RASPRAVA}

Prvu eksperimentalnu transplantaciju bubrega, neovisno jedan o drugome, učinili su Emerich Ullmann (Beč) i Alexis Carell (Lyon) 1902. godine ${ }^{3}$. U tom početnom razdoblju kirurške komplikacije nisu bile rijetke. Napredak kirurške tehnike, kao i poboljšanje imunosupresivne terapije, imali su i značajni utjecaj na smanjenje učestalosti kirurških i uroloških komplikacija. No, urološke komplikacije nakon transplantacije bubrega i dalje su relativno česte, a njihova pojavnost je udružena sa značajnim morbiditetom, oštećenjem bubrežne funkcije, a u nekih pacijenata s gubitkom grafta, pa i smrću. Urološke komplikacije javljaju se u 2,5 - $30 \%$ pacijenata u kojih je učinjena transplantacija bubrega ${ }^{4-7}$. Većina tih komplikacija je vezana uz ureter odnosno ureterovezikalnu anastomozu. Većinu uroloških komplikacija (i do 82,5 \%) koje zahtijevaju kirurško liječenje moguće je riješiti endourološkim putem, bez potrebe otvorenog kirurškog pristupa ${ }^{8-10}$. U našem centru učestalost uroloških komplikacija je bila 13,3 \%. Vidljivo je (tablica 3 ) kako je promjena kirurške tehnike u oblikovanju ureteralne anastomoze dovela do značajnog smanjenja uroloških komplikacija (pogotovo urinarnih fistula i urolitijaze).

Stenoza uretera najčešća je urološka komplikacija nakon transplantacije bubrega i čini do $50 \%$ svih uroloških komplikacija ${ }^{8,12-14}$. Učestalost stenoze uretera u transplantiranih pacijenata kreće se od $0,6-10,5 \%^{10}$. Većina pacijenata $(60-95 \%)$ ima stenozu u području ureterovezikalne anastomoze koja nastaje zbog nastanka fibroze na mjestu anastomoze $^{8}$. Kasna stenoza uretera se u prosjeku javlja 5,4- 17 mjeseci nakon transplantacije, dok je desetogodišnji rizik od njezina javljanja $9 \%^{8}$. Neke studije pokazale su kako je kasna stenoza uretera češća u muškaraca ${ }^{8}$. Mogući uzroci nastanka stenoze uretera su kirurška tehnika, ishemija uretera (najvažniji uzrok), imunološki čimbenici, periureteralne limfocele, akutno i kronično odbacivanje, upale i imunosupresivni lijekovi $^{15,16}$. Rane stenoze (unutar 90 dana po transplantaciji) obično su posljedica kirurške tehnike ili negativnoga utjecaja na vaskularizaciju uretera tijekom zahvata. Kasne stenoze mogu biti uzrokovane infekcijom, fibrozom, progresijom vaskularne insuficijencije i/ili odbacivanjem ${ }^{17-19}$.

Posebice treba naglasiti važnost eksplantacijske tehnike i pripreme bubrega za transplantaciju gdje treba očuvati periureteralnu mast i tzv. „zlatni trokut" (trokut omeđen ureterom, donjim polom bubrega te renalnom arterijom) ${ }^{12}$. Naime, narušavanje opskrbe uretera krvlju može dovesti do ishemijskih promjena koje mogu dovesti do stenoze uretera, pa čak i do njegove nekroze. Nekroza distalnog dijela uretera javlja se u $70 \%$ pacijenata u kojih je učinjena ekstenzivna disekcija tkiva u području „zlatnog trokuta“20. Duljina spatulacije uretera također može utjecati na pojavnost stenoza. Asadpour i sur. pokazali su kako spatulacija uretera dulja od $10 \mathrm{~mm}$ dovodi do značajnog smanjenja učestalosti stenoza na ureterovezikalnoj anastomozi ${ }^{21}$. Dokazano je i kako do razvoja kasne stenoze uretera može dovesti i infekcija BK virusom ${ }^{22}$.

Klinički značajne stenoze uretera manifestiraju se hidronefrozom s negativnim utjecajem na bubrežnu funkciju. Osnovni pristup takvom pacijentu uključuje antegradnu pijeloureterografiju kojom se prikaže mjesto i duljina stenoze uz postavljanje perkutane nefrostomije ${ }^{11}$. Alternativno, može se učiniti retrogradna ureteropijelografija i postaviti JJ endoproteza, ali je to najčešće, zbog atipičnog položaja ureteralnog ušća, veoma teško. Daljnje liječenje ovisi o vremenu nastanka stenoze, duljini stenoze, oporavku bubrežne funk- 
cije, pacijentovu habitusu i komorbiditetima te iskustvu kirurga odnosno transplantacijskoga centra. Stenoza uretera kraća od $3 \mathrm{~cm}$ može se liječiti endourološki, antegradnim ili retrogradnim pristupom (balonska dilatacija ili laserska ureterotomija). Uspjeh endoskopskog liječenja je oko $50 \%{ }^{17,23-26}$. U slučaju rekurentnih stenoza nakon primarnog endourološkog liječenja kao i kod stenoza duljih od $3 \mathrm{~cm}$, preporučuje se kirurško liječenje otvorenim ili laparoskopskim pristupom ${ }^{17,19}$. Ovakav tip liječenja uključuje reimplantaciju uretera, pijelovezikalnu anastomozu (s ili bez psoas-hitcha i/ili Boari flapa) ili u pacijenata s normalnim nativnim ureterom pijelo(uretero)-ureterostomiju ${ }^{17,26-28}$.

U naših pacijenata stenoza uretera bila je najčešća urološka komplikacija (52 pacijenta - 4,5 \%). Nešto je učestalija bila u drugom razdoblju, no to može biti posljedica duljine drugog razdoblja, duljem preživljenju i grafta i pacijenata te boljoj dijagnostici. Maleni broj stenoza (5/52 - 9,6\%) uspješno je liječen konzervativno (privremeno postavljanje perkutane nefrostomije), a sve ostale su zahtijevale kirurško liječenje. U posljednja dva desetljeća te pacijente smo pokušavali riješiti endourološkim pristupom uz efikasnost od oko $50 \%$, što je podudarno s podacima iz literature. U slučaju rekurentnih ili duljih stenoza najčešće smo koristili anastomozu na nativni ureter. $U$ prvo vrijeme radili smo ureteroureteralnu anastomozu, ali smo kasnije prešli na pijeloureteralnu anastomozu. Najučinkovitija nam se pokazala terminolateralna anastomoza između pijelona grafta i nativnoga uretera ${ }^{29}$. Sigurnost metode je vjerojatno rezultat nedirnute vaskularizacije nativnoga uretera. Ovom operacijom izbjegavamo nefrektomiju nativnog bubrega ili podvezivanje nativnog uretera proksimalno od anastomoze. Time smanjujemo rizik od hidronefroze nativnog bubrega i nastanka urinarne infekcije.

Urinarna fistula nakon transplantacije bubrega javlja se u $0-9,3 \%$ transplantiranih pacijenata ${ }^{30}$. Ona se najčešće javlja u području uretera ili mjehura $^{31}$. Najčešći uzroci su kirurška tehnika i/ili nekroza uretera ${ }^{18,32}$. Čimbenici nevezani za tehnički aspekt su dob pacijenata, broj renalnih arterija, mjesto arterijske anastomoze, učestalost epizoda akutnog odbacivanja, problemi s mjehurom te imunosupresivni protokol ${ }^{33}$. Urinarna fistula se manifestira smanjenom diurezom te povećanom drenažom, a analiza drena pokazuje visoke vrijednosti kreatinina ${ }^{18}$. Kako bi se smanjio rizik nastanka nekroze neoophodno je sačuvati vaskularizaciju distalnog dijela uretera ${ }^{18}$. Također se preporučuje i rutinsko korištenje JJ endoproteze ${ }^{17,32,34}$. Liječenje urinarne fistule ovisi o njezinu mjestu (pijelon, proksimalni ili distalni ureter te mokraćni mjehur), vremenu nastanka i volumenu fistule. Za rane i fistule maloga volumena liječenje može biti

Stenoza uretera i urinarna fistula najčešće su urološke komplikacije nakon transplantacije bubrega. U malog broja pacijenata ove komplikacije mogu se liječiti konzervativno. $U$ većine pacijenata neophodno je kirurško liječenje čiji prvi korak predstavlja uporaba endouroloških metoda. U slučaju neuspjeha minimalno-invazivnih metoda neophodno je komplikacije riješiti koristeći laparoskopski ili otvoreni pristup.

konzervativno (urinski kateter, perkutana nefrostomija, JJ endoproteza) ${ }^{35}$. U slučaju neuspjeha konzervativne terapije ili ako se radi o fistuli obilnije drenaže, nužno je kirurško liječenje. U tih pacijenata može se učiniti reimplantacija uretera u mokraćni mjehur ili anastomoza na nativni ureter s podjednakim rezultatom ${ }^{35,36}$.

$U$ našem prvom razdoblju imali smo značajan broj urinarnih fistula (25 pacijenata - 17,8\%). Većina njih je očekivano nastala na ureteroureteralnoj anastomozi (16 pacijenata), ali u jednog pacijenta došlo je do razvoja kalikokutane fistule. U osam pacijenata je urinarna fistula bila vezana uz drenažnu protezu urinarne anastomoze. Većina fistula je uspješno liječena konzervativnim pristupom, a u jednog pacijenta (kalikokutana fistula) trebalo je učiniti graftektomiju. Značajan broj urinarnih fistula nas je potaknuo na promjenu operativne tehnike, te smo umjesto ureteroureteralne anastomoze počeli koristiti ekstravezikalnu ureterocistoneostomiju (modifikacija Lich-Gregoir tehnike) uz korištenje ureteralne proteze ${ }^{37}$. To je dovelo do značajnog smanjenja broja urinarnih fistula (25 pacijenata $2,45 \%$ ) u drugom razdoblju. I u drugim centrima je korištenje ekstravezikalne anastomoze uretera dovelo do značajnog smanjenja uroloških kompli- 
kacija ${ }^{7,38,39}$. Iz tablice 2 vidljivo je kako je većina pacijenata u drugom razdoblju morala biti liječena kirurški, pogotovo oni u kojih je došlo do razvoja nekroze uretera. Pri tome su korištene različite kirurške tehnike od relativno jednostavnih kao, primjerice, postavljanje dodatnih šavi na ureterovezikalnu anastomozu do mnogo složenijih zahvata prilikom kojih je korišten segment tankog crijeva za nadomještanje uretera (pijeloileocistoplastika). U dvoje pacijenata s urinarnom fistulom došlo je do smrtnog ishoda (plućna embolija i sepsa).

Urolitijaza nije česta komplikacija nakon transplantacije bubrega (0,4 - $1 \%$ svih učinjenih transplantacija $)^{40}$. Mogući čimbenici njezinog nastanka u ove skupine pacijenata su hiperparatireoidizam, ureteralna opstrukcija, kronični zastoj urina, imunosupresivni lijekovi (ciklosporin), strana tijela (primjerice neresorptivni šavi), vezikoureteralni refluks, metaboličke bolesti (urična dijateza, hiperoksalurija) te otprije prisutan kamenac u darovanom bubregu ${ }^{41}$. S obzirom na izostanak inervacije transplantiranog bubrega i uretera, urolitijaza se ne manifestira renalnom kolikom već najčešće pogoršanjem bubrežne funkcije i hidronefrozom $^{42,43}$. U današnje vrijeme se u liječenju urolitijaze u transplantiranih pacijenata, kao i u standardne populacije, koriste minimalno-invazivne metode. Ove metode uključuju ureterorenoskopiju (prvenstveno fleksibilnu ureterorenoskopiju), perkutanu nefrolitotripsiju i ESWL ${ }^{42,44-47}$. U manjeg broja pacijenata urolitijaza se rješava laparoskopskim ili otvorenim pristupom. Općenito je broj naših transplantiranih pacijenata s urolitijazom bio malen $(8 / 1160=0,7 \%)$. U prvom razdoblju pet je pacijenata liječeno radi urolitijaze koja je najčešće nastajala u području ureteroureteralne anastomoze. U većine pacijenata (4/5) provedeno je kirurško liječenje otvorenim pristupom. Naime, u to vrijeme nisu postojale razvijene minimalno-invazivne metode. $U$ drugom periodu zbog urolitijaze liječena su samo tri pacijenta. U jednoga pacijenta učinjena je ureteroileocistoplastika. U drugoga pacijenta je kamenac u pijelonu uspješno liječen miniperkutanom nefrolitotripsijom uz pomoć lasera. Uzrok nastanku kamenca je bila stenoza ureterovezikalne anastomoze te je istovremena učinjena i antegradna balonska dila- tacija stenoziranog dijela. $\mathrm{U}$ trećeg pacijenta, u kojega je zbog karcinoma mokraćnoga mjehura učinjena radikalna cistektomija i nakon toga Mainz-pouch I došlo je do stvaranja kamenca u pouchu nekoliko godina po transplantaciji. On je efikasno usitnjen endoskopski uz pomoć elektrohidraulike. lako nije transplantiran u našem centru, godine 2007. učinili smo i ESWL kamenca u bubregu u pacijenta kojemu je učinjena en-bloc transplantacija ${ }^{48}$. Iz naših rezultata vidljivo je kako je promjena metode implantacije uretera smanjila i učestalost urolitijaze, a minimalno-invazivne metode su postale dominantne u rješavanju urolitijaze u transplantiranih pacijenata.

Benigna hiperplazija prostate (BPH) je česta bolest u muškaraca i njezina učestalost raste $s$ godinama. U SAD-u više od $70 \%$ muškaraca starosti između 60 i 69 godina ima $\mathrm{BPH}^{49}$. No, postojanje hiperplazije i povećanja prostate ne mora značiti da pacijent ima i smetnje s mokrenjem. U slučaju kada postoji subvezikalna opstrukcija protoku urina govorimo o opstrukciji na izlazu iz mjehura (BOO od engl. bladder outlet obstruction). Ona je najčešće uzrokovana BPH-om, no i drugi uzroci, poput strikture uretre i skleroze vrata mokraćnog mjehura, mogu biti uzrok ovom stanju. Učestalost BOO-a koji se može pripisati BPH-u kod transplantiranih pacijenata se prijeoperacijski ponekada zanemaruje jer su pacijenti podvrgnuti dijalitičkom liječenju oligurični ili anurični. No, nakon uspješne transplantacije i uspostavljanja diureze opstrukcija protoka urina i simptomi donjeg mokraćnog sustava postaju evidentni te dovode do značajnih smetnji mokrenja, kao i mogućeg negativnog utjecaja na graft $^{50}$. Volpe i sur. pokazali su kako je 32,8 \% muških transplantiranih pacijenata starijih od 40 godina razvilo smetnje mokrenja nakon transplantacije ${ }^{51}$. Prosječna dob pacijenata u završnom stadiju bubrežnog zatajenja neprestano raste, pa je tako medijan dobi novih pacijenata 2014. godine u Republici Hrvatskoj bio 67 godina ${ }^{52}$. S obzirom na to da je dob pacijenata sa završnim stadijem bubrežnog zatajenja sve veća, pa tako i onih transplantiranih, za očekivati je da ćemo imati sve veći broj transplantiranih pacijenata s BOO-om. U novije vrijeme postoji medikamentozna terapija, u prvom redu blokatori alfa adrenergičkih recep- 
tora i inhibitori 5 alfa reduktaze, koji su djelotvorni u liječenju smetnji mokrenja u većine pacijenata. U pacijenata u kojih je neophodno kirurško liječenje zlatni standard je transuretralna resekcija prostate (TURP). Studije su pokazale kako je TURP nakon transplantacije bubrega sigurna i učinkovita metoda s dugotrajnim povoljnim učinkom na mokrenje, ali i na funkciju grafta ${ }^{51,53}$. Također, preporučuje se da od transplantacije do TURP-a prođe barem mjesec dana kako bi ureterovezikalna anastomoza zacijelila. TURP je moguće učiniti i prije transplantacije, no u oliguričnih ili anuričnih pacijenata povećana je sklonost nastanku skleroze vrata mjehura i/ili strikture uretre ${ }^{54}$. U skupini naših pacijenata uzroci BOO-a bili su skleroza vrata mjehura (šest pacijenata - od toga $u$ jedne ženske pacijente), BPH (13 pacijenata) i striktura uretre (četiri muška pacijenta). U pacijenata sa sklerozom vrata mjehura učinjena je discizija vrata u oba spola, kod BPH-a učinjen je TURP te interna uretrotomija kod strikture uretre ${ }^{55}$. U jednog pacijenta rezultat liječenja nije bio dobar te je i nakon operacijskog liječenja imao trajni urinski kateter. Radilo se o pacijentu sa šećernom bolešću i perifernom neuropatijom koja je dovela do razvoja hipokontraktilnoga detruzora.

Ukupno je u 3 (0,25 \%) pacijenata s urološkom komplikacijama (dva pacijenta s urinarnom fistulom i jedan s urolitijazom) došlo do smrtnog ishoda kao posljedica komplikacije uz funkcionirajući graft. Kod jednoga pacijenta s urinarnom fistulom došlo je do razvoja pneumonije i sepse, a kod drugoga do plućne embolije. Kod pacijenta u kojega je zbog urolitijaze učinjena ureteroileocistoplastika uzrok smrti bilo je zatajenje jetre. U dvoje je pacijenata $(0,17 \%)$ bilo potrebno učiniti transplantektomiju zbog uroloških komplikacija. U posljednje vrijeme primjećuje se porast rješavanja uroloških komplikacija minimalno-invazivnim metodama, prvenstveno uz pomoć endourologi$\mathrm{je}^{8,9,35}$. Na taj način se minimalno oštećuje graft uz visoku efikasnost metoda i kraću hospitalizaciju. U slučaju neuspjeha ovih metoda može se učiniti daljnje liječenje otvorenim ili laparoskopskim pristupom.

Ovo je retrospektivna studija u kojoj su predstavljeni rezultati jednog transplantacijskog centra te je samim time i limitirana. No, vjerujemo da bi se slični rezultati našli i u drugim transplantacijskim centrima u našoj zemlji i bližem okruženju.

\section{ZAKLJUČAK}

Tijekom više od 40 godina učinili smo 1160 transplantacija bubrega. Urološke komplikacije nisu bile česte, a najčešće su bile stenoza uretera i urinarna fistula. Dio uroloških komplikacija liječen je konzervativnim, a dio kirurškim pristupom. U pacijenata u kojih je bilo indicirano kirurško liječenje endourološke metode danas predstavljaju metodu prvog izbora. U slučaju neuspjeha endouroloških metoda, ili ako se radi o komplikacijama koje nisu pogodne za liječenje minimalno-invazivnim metodama, treba pristupiti otvorenom kirurškom liječenju.

\section{ZAHVALA}

Za izradu ovog rada zahvaljujemo svim bivšim i sadašnjim djelatnicima Klinike za urologiju, bez čijeg udjela ovaj rad ne bi mogao nastati.

Izjava o sukobu interesa: Autori izjavljuju da ne postoji sukob interesa.

\section{LITERATURA}

1. Purnell TS, Auguste P, Crews DC, Lamprea-Montealegre J, Olufade T, Greer R et al. Comparison of life participation activities among adults treated by hemodialysis, peritoneal dialysis and kidney transplantation:a systematic review. Am J Kidney Dis 2013;62:953-73.

2. Wong G, Howard K, Chapman JR, Chadban S, Cross N, Tong $A$ et al. Comparative survival and economic benefits of deceased donor kidney transplantation and dialysis in people with varying ages and co-morbidities. PLOS One 2012;7:e29591.

3. Markić D, Valenčić M, Maričić A, Španjol J, Rački S, Fučkar Ž. Kidney transplantation - successful story started 110 years ago. Acta Med Croatica 2012;66:59-63.

4. Neri F, Tsivian M, Coccolini F, Bertelli R, Cavallari G, Nardo $B$ et al. Urological complications after kidney transplantation: experience of more than 1.000 transplantations. Transplant Proc 2009;41:1224-6.

5. Slagt IK, ljzermans JN, Visser LJ, Weimar W, Roodnat JI, Terkivatan T. Independent risk factors for urological complications after deceased donor kidney transplantation. PLoS One 2014;9:e91211.

6. Buttigieg J, Agius-Anastasi A, Sharma A, Halawa A. Early urological complications after kidney transplantation: an overview. World J Transplant 2018;8:142-9.

7. Carvalho JA, Nunes P, Antunes H, Parada B, Tavares da Silva $E$, Rodrigues $L$ et al. Surgical complications in kidney transplantation: an overview of a Portuguese Reference Center. Transplant Proc 2019;51:1590-6.

8. Krajewski W, Dembowski J, Kolodziej A, Malkiewicz B, Tupikowski K, Matuszewski M et al. Urological complica- 
tions after renal transplantation - a single centre experience. Cent European J Urol 2016;69:306-11.

9. Ozkaptan O, Sevinc C, Balaban M, Karadeniz T. Minimally invasive approach for the management of urological complications after renal transplantation: single center experience. Minerva Urol Nefrol 2018;70:422-8.

10. Basiri A, Nikoobakht MR, Simforoosh N, Moghaddam SM. Ureteroscopic management of urological complications after renal transplantation. Scand J Urol Nephrol 2006;50:53-6.

11. Breda A, Bui MH, Liao JC, Gritsch HA, Schulam PG. Incidence of ureteral strictures after laparoscopic donor nephrectomy. J Urol 2006;176:1065-8.

12. Keller $\mathrm{H}$, Noldge $\mathrm{G}$, Wilms $\mathrm{H}$, Kirste $\mathrm{G}$. Incidence, diagnosis, and treatment of ureteric stenosis in 1298 renal transplant patients. Transpl Int 1994;7:253-7.

13. Fontana I, Bertocchi M, Rossi AM, Gasloli G, Santori G, Barabani $C$ et al. Late ureteral stenosis after kidney transplantations: a single-center experience. Transplant Proc 2010;42:1174-5.

14. Mano R, Golan S, Holland R, Livne PM, Lifshitz DA. Retrograde endoureterotomy for persistent ureterovesical anastomotic strictures in renal transplant kidneys after failed antegrade balloon dilation. Urology 2012;80:2559.

15. Duty BD, Conlin MJ, Fuchs EF, Barry JM. The current role of endourologic management of renal transplantation complications. Adv Urol 2013;2013:246520.

16. Giessing M. Transplant ureter stricture following renal transplantations: surgical options. Transplant Proc 2011;43:383-6.

17. Breda A, Budde K, Figueiredo A, Lledo-Garcia E, Olsburgh $\mathrm{J}$, Regele H. EAU guidelines on renal transplantation. European Association of Urology Guidelines, 2019.

18. Dinckan A, Tekin A, Turkyilmaz S, Kocak H, Gurkan A, Erdogan $O$ et al. Early and late urological complications corrected surgically following renal transplantation. Transpl Int 2007;20:702-7.

19. Helfand BT, Newman JP, Mongiu AK, Modi P, Meeks JJ, Gonzalez CM. Reconstruction of late-onset transplant ureteral stricture disease. BJU Int 2011;107:982-7.

20. Krol R, Ziaja J, Chudek J, Heitzman M, Pawlicki J, Wiecek A et al. Surgical treatment of urological complications after kidney transplantation. Transplant Proc 2006;38:12730.

21. Asadpour A, Molaei M, Yaghoobi S. Management of ureteral complications in renal transplantation: pevention and treatment. Saudi J Kidney Dis Transpl 2011;22:72-4.

22. Hirsch HH, Steiger J. Polyomavirus BK. Lancet Infect Dls 2003;3:611-23.

23. Kaskarelis I, Koukoulaki M, Georgantas T, Bairamidis E, Kokkinos $\mathrm{C}$, leronymou $\mathrm{M}$ et al. Ureteral complications in renal transplant recipients successfully treated with interventional radiology. Transplant Proc 2008;40:3170-2.

24. Gabr AH, Sung RS, Samaniego-Picota MD, He C, Wolf JS Jr. Ureteral complications after hand-assisted laparoscopic living donor nephrectomy. Transplantation 2014; 97:788-92.

25. Kristo B, Phelan MW, Gritsch HA, Schulam PG. Treatment of renal transplant ureterovesical anastomotic strictures using antegrade balloon dilation with or without holmium:YAG laser endoureterotomy. Urology 2003;62: 831-4.
26. Markić $D$, Valenčić $M$, Maričić $A$, Oguić $R$, Sotošek $S$, Španjol $J$ et al. Retrogradna balonska dilatacija kao minimalno invazivni oblik liječenja stenoze uretera. Lijec Vjesn 2012;134:281-5.

27. Nie Z, Zhang K, Huo W, Li Q, Zhu F, Jin F. Comparison of urological complications with primary ureteroureterostomy versus conventional ureteroneocystostomy. Clin Transplant 2010; 24:615-9.

28. Chaykovska L, Deger S, Wille A, Friedersdorff F, Kasper A, Dragun $D$ et al. Kidney transplantation into urinary conduits with ureteroureterostomy between transplant and native ureter: single-center experience. Urology 2009; 73:380-5.

29. Maričić $A$, Orlić $P$, Valenčić $M$, Oguić $R$, Sotošek $S$, Markić $D$ et al. Surgical procedure and urologic complications after 922 kidney transplantations: our experience. Acta Med Croatica 2011;65:20-3.

30. Kayler L, Kang D, Molmenti E, Howard R. Kidney transplant ureteroneocystostomy techniques and complications: review of the literature. Transplant Proc 2010; 42:1413-20.

31. Secin FP, Rovegno AR, Marrugat RE, Virasoro R, Lautersztein GA, Fernandez H. Comparing Taguchi and Lich-Gregoir ureterovesical reimplantation techniques for kidney transplants. J Urol 2002;168:926-30.

32. Kumar A, Verma BS, Srivastava A, Bhandari M, Gupta A, Sharma R. Evaluation of the urological complications of living related renal transplantation at a single center during the last 10 years: impact of the Double-J* stent. J Urol 2000;164:657-60.

33. Mazzucchi E, Souza GL, Hisano M, Antonopoulos IM, Piovesan AC, Nahas WC et al. Primary reconstruction is a good option in the treatment of urinary fistula after kidney transplantation. Int Braz J Urol 2006;32:398-403.

34. Davari HR, Yarmohammadi H, Malekhosseini SA, Salahi $H$, Bahador A, Salehipour M. Urological complications in 980 consecutive patients with renal transplantation. Int J Urol 2006;13:1271-5.

35. Sabnis RB, Singh AG, Ganpule AP, Chhabra JS, Tak GR, Shah JH. The development and current status of minimally invasive surgery to manage urological complications after renal transplantation. Indian J Urol 2016;32:186-91.

36. Suttle T, Fumo D, Baghmanli Z, Saltzman B, Ortiz J. Comparison of urologic complications between ureteroneocystostomy and ureteroureterostomy in renal transplant: a meta-analysis. Exp Clin Transplant 2016;14:276-81.

37. Orlić $P$, Šepić A, Budisavljević B, Ćuruvija D, Dimec D, Franulović $B$ et al. Emergency surgical conditions after renal transplantation. Acta Chir lugosl 1989;36:111-4.

38. Ameer A, Aljiffry M, Jamal M, Hassanain M, Doi S, Fernandez $\mathrm{M}$ et al. Complications of ureterovesical anastomosis in adult renal transplantation: comparison of the Lich-Gregoire and the Taguchi techniques. Ann Transplant 2011;16:82-7.

39. Slagt IK, Klop K, ljzermans JN, Terkivatan T. Intravesical versus extravesical ureterocystostomy in kidney transplantation: a systematic review and meta-analysis. Transplantation 2012;94:1179-84.

40. Rhee BK, Bretan PN Jr, Stoller ML. Urolithiasis in renal and combined pancreas/renal transplant recipients. J Urol 1999;161:1458-62.

41. Klingler HC, Kramer G, Lodde M, Marberger M. Urolithiasis in allograft kidneys. Urology 2002;59:344-8. 
42. Challacombe B, Dasgupta P, Tiptaft R, Glass J, Koffman G, Goldsmith $D$ et al. Multimodal management of urolithiasis in renal transplantation. BJU Int 2005;96:385-9.

43. Crook TJ, Keoghane SR. Renal transplant lithiasis: rare but time-consuming. BJU Int 2005;95;931-3.

44. Ji ZG, Tian Y, Chen Q, Liu Z, Lin J, Wang JM et al. A retrospective study of minipercutaneous laser lithotripsy for treatment of allograft kidney lithiasis obstruction. Transplant Proc 2013;45:3298-301.

45. Rifaioglu MM, Berger AD, Pengune W, Stoller ML. Percutaneous management of stones in transplanted kidneys. Urology 2008;72:508-12.

46. Markić D, Krpina K, Ahel J, Gršković A, Španjol J, Rubinić $\mathrm{N}$, Materljan $\mathrm{M}$ et al. Treatment of kidney stone in a kidney-transplanted patient with mini-percutaneous laser lithotripsy: a case report. Case Rep Nephrol Dial 2016;6: 26-31.

47. Atala A, Steinbeck GS, Harty JI, Klein JB. Extracorporeal shock-wave lithotripsy in transplanted kidney. Urology 1993;41:60-2.

48. Markić $D$, Valenčić $M$, Gršković $A$, Španjol J, Sotošek $S$, Fučkar Ž et al. Extracorporeal shockwave lithotripsy of ureteral stone in a patient with en bloc kidney transplantation: a case report. Transplant Proc 2011;43:2110-2.

49. Wei JT, Calhoun E, Jacobsen SJ. Urologic diseases in america project: benign prostatic hyperplasia. J Urol 2008;179:S75-80.
50. Mitsui T, Shimoda N, Morita K, Tanaka H, Moriya K, Nonomura K. Lower urinary tract symptoms and their impact on quality of life after successful renal transplantation. Int J Urol 2009;16:388-92.

51. Volpe A, Billia M, Quaglia M, Vidali M, Marchioro G, Ceratti $G$ et al. Transurethral resection of the prostate in kidney transplant recipients: urological and renal functional outcomes at long-term follow-up. BJU Int 2013; 112:386-93.

52. Hrvatsko društvo za nefrologiju, dijalizu i transplantaciju [Internet]. Hrvatski registar nadomještanja bubrežne funkcije. Izvještaj za 2014. godinu. [Cited 10 November 2019]. Available from: https://www.hdndt.org/registar/ hrn14.html.

53. Mokos I, Kaštelan Ž, Bašić-Jukić N, Kes P, Pasini J. Transurethral incision/resection of the prostate (TUIP/ TURP) in operative treatment of repeated bladder outlet obstruction early after kidney transplantation. Acta Clin Croat 2011;50:381-4.

54. Tsaur I, Jones J, Melamed RJ, Blaheta RA, Gossmann J, Bentas W. Postoperative voiding dysfunction in older male renal transplant recipients. Transplant Proc 2009; 41:1615-8.

55. Markić $D$, Valenčić $M$, Maričić $A$, Krpina K, Rahelić D, Ahel $J$ et al. Transurethral incision of the bladder neck in a woman with primary bladder neck obstruction after kidney transplantation. Case Rep Transplant 2015; 2015: 312084. 